Vozes do Nordeste 


\title{
Graciliano Ramos, \\ uma poética da insignificância
}

\author{
ERWIN TORRALBO GIMENEZ
}

\begin{abstract}
"Afirmava-me não ser difícil percorrermos um texto, apreendendo a essência e largando o pormenor. Isso me desagradava. São as minúcias que me prendem, fixo-me nelas, utilizo insignificâncias na demorada construção das minhas histórias. Aquele entendimento rápido, afeito a saltos vertiginosos e complicadas viagens, contrastava com as minhas pequeninas habilidades que pezunhavam longas horas na redação de um período. Julguei Sérgio isento de emoção, e isto me aterrou. Comovo-me em excesso, por natureza, e por ofício, acho medonho alguém viver sem paixões."
\end{abstract}

(Graciliano Ramos - Memórias do cárcere)

A PESQUISA de um estilo literário, ao perseguir as linhas do seu núcleo expressivo no passo do tempo, resvala em inflexões que prenunciam, talvez, movimentos mais largos da cultura. Trata-se de recolher, na obra particular, certas inquietudes adiante entrevistas como matizes de uma nova geração. Sucede, nesse sentido, perguntar: por que Graciliano Ramos abandonou a forma romance após Vidas secas (1938), apesar de nunca desistir da literatura até morrer em 1953? Sensível aos problemas da mimese, o escritor não só construiu o tratamento estético mais justo na narrativa de 30 , graças ao equilíbrio clássico, mas também soube perceber o esfacelamento dos motivos que sustinham aquela conjuntura, intuindo assim em seu estilo os riscos do processo artístico. Na lista dos seus livros, vemos um salto de sete anos de Vidas secas a Infância e, especialmente, $\mathrm{o}$ trânsito da escrita ficcional às páginas confessionais, onde o corte lírico cresce e se resguarda na própria subjetividade, à semelhança aliás dos rumos da literatura brasileira. Todavia, há nessa aparente lacuna uma vasta produção, em parte inédita ou esquecida, cujo caráter fragmentário insinua o desconcerto. Convém, logo, investigar a atitude do autor no decênio de 1940, mesmo em seus desalinhos, no intento de acompanhar o percurso crítico que se abre dos valores culturais à singularidade criativa.

Otto Maria Carpeaux, num ensaio de 1948, aceita a difícil tarefa de conjecturar as tendências do romance brasileiro na década. Ocorre-lhe um indício ao deparar com os volumes de sua estante: ao longo dos períodos, os romances ganharam tamanho maior. Os títulos de 30 aumentaram, efetivamente, a largura das narrativas. A despeito de averiguar que já estava diluída a dissensão entre as vertentes esquerdizante e espiritualista, Carpeaux (2005) recupera aquela rixa para deduzir com algum espírito: 
Graciliano Ramos seria neonaturalista ou introspectivo? Na verdade, todos os gêneros são iguais perante Deus, em que meu amigo Graciliano não acredita. Os elementos constitutivos são os mesmos em todo romance: enredo, caracteres e estilo, este último definido como maneira de apresentação de enredo e caracteres.

Recorre, assim, às categorias estilísticas propostas por Percy Lubbock, em A técnica da ficção - panorâmico e dramático -, a fim de cogitar os manejos constantes da nossa tradição quanto aos elementos antes referidos. Tais maneiras de tratamento, convertidas à questão do tamanho, levam a pensar dois critérios que ampliam o fôlego do romance: a descoberta de novos ambientes sociais ou a concepção de nova técnica novelística. E, tendo desdobrado a hipótese em diferentes literaturas, nas quais percebe de fato ciclos de ampliação e concentração consonantes com aqueles critérios, Carpeaux a projeta no itinerário brasileiro: se, em seu início, o romance nacional se fez reduzido em tamanho, porque o ambiente era limitado e a técnica lhe chegava fixada por modelos estrangeiros, em 1930 cada uma das vertentes teria dilatado as proporções narrativas - ou por descobrir novo ambiente social ou por formular nova mentalidade. Em 1940, por sua vez, encerrou-se o período extensivo, e, agindo os reveses sobre as ideias, as perspectivas surgem mais encentradas. Cumpriria, sem dúvida, refinar essa hipótese em estudos monográficos, porém ela nos oferece, em seus grandes pulos, uma vista do fenômeno: o esforço de interpretação dos anos 1930, embora sob diferentes ópticas, parece descender na segunda metade da década e, depois, refletir o encolhimento subjetivo em formas breves.

Poucos anos antes, em 1942, Carpeaux circundou a singularidade de Graciliano Ramos, nos termos aqui sugeridos, ao conceituar o seu estilo como lírico, isto é, atido à busca da síntese:

O lirismo de Graciliano Ramos, porém, é bem estranho. Não tem nada de musical, nada do desejo de dissolver em canto o mundo das coisas. [...] Não quer dissolver o mundo agitado, quer fixá-lo, estabilizá-lo. Elimina implacavelmente tudo o que não se presta a tal obra de escultor, dissolve-o em ridicularias, para dar lugar aos seus monumentos de baixeza. (Carpeaux, 1986)

Tal estilo, portanto, depura a forma, a partir de um entalhamento clássico, para melhor depreender da modernidade o seu cerne impuro, infernizado, pois faz emergir o sujeito que nela se aflige e se compunge; quanto mais o seu senso lúcido de escritor se contrai, mais aguda se torna a sua investida sobre os objetos, declinando assim até o limite da tensão entre o eu e o mundo, entre o tempo e o espaço, entre a vida onírica e a vida vivida. ${ }^{1}$ Nessa direção, a veia dramática de Graciliano Ramos, cujo lirismo é estranho a ponto de não se dissipar no mundo, torna o enlace ainda mais espinhoso quando, na época de reviravolta, o mundo já dissipa o sujeito; com isso, a perspectiva se comprime para conservar a tensão em alto plano.

Com efeito, reúnem-se e completam-se os dois ensaios: infenso aos cortes restritivos, na arte de ficção, tal lirismo dramático forjou, em 1930, romances 
que se expandiam no perímetro de uma técnica pessoal, quer dizer, perfuravam as superficies e lhes impunham um obstáculo - a individualidade. Elevou-se acima do documento e do intimismo, pois logrou entrosá-los numa fatura coesa, em virtude do ângulo de narrador. Eis a causa da sua permanência, mesmo fechado o ciclo que representou. Entretanto, como superou o seu tempo, também anteviu o momento de fecho; escreveu os melhores livros de 1930 e foi o primeiro a abandoná-los. Não cabia na sua consciência outra forma romanesca senão aquela capaz de conjugar os traçados subjetivo e objetivo em chave de conflito - sem poder reanimá-la, preferiu o silêncio, ou melhor, resistiu ao silêncio com a última reserva de afetividade: a memória.

Angústia e Vidas secas parecem consumar, sem quebra de coerência, os dois exercícios extremos, em relação à ironia do escritor. ${ }^{2}$ A consciência formadora do romancista, que deve elaborar esteticamente os valores de sua ética, precede e extravasa o ponto de vista da personagem, a qual se move nos raios do evento e ali encarna a tensão cujo nível (do crítico ao ingênuo) se regula pelo grau de oposição ou adesão ao mundo objetivo. Sob o crivo problemático, o autor Graciliano Ramos passa do ângulo da primeira pessoa, plasmado ora até o marco irônico máximo, ou seja, a aproximação maior ao narrador-protagonista, para o ângulo da terceira pessoa, de igual modo até o limite irônico, ora o afastamento maior dos entes ficcionais. Em Angústia, à medida que instaura um narrador tão próximo ao seu perfil social e psicológico, o pobre-diabo, riscando ao redor dele os mesmos esquemas do seu infortúnio, compreende o pathos de um tempo, agitado e enervante, e empurra a personagem para a fronteira do lírico; em Vidas secas, a mesma ética vigilante recusa o mundo, mas em nome da verossimilhança o faz por meio de uma voz narrativa que atravessa as consciências precárias, historicamente esmagadas, sem misturar-se com elas, pois the concerne analisar o drama sem perder-se no trágico. ${ }^{3}$

Com os dois experimentos, radicais no corpo da sua linhagem estilística, o escritor explorou o quanto podia a estrutura do romance, esquivando-se de figurar quer o esvaziamento do herói, quer o eclipse da busca de sentido; esses caminhos, não apenas válidos como necessários para a sobrevida da forma, não se quadravam, repito, na visão do autor. Resulta, então, consequente que ele enveredasse pelas memórias porque, se a mediação épica, até mesmo como ironia moderna, se partira, restava à ética criadora volver sobre si própria, como resistência do sujeito diante da desorientação geral. Nem aí, contudo, a expressão suplanta em definitivo a representação (vale o reverso: na ficção se exprimia o autor), falando quase sempre um eu constrangido que se põe no lugar de testemunha. Nas páginas de Infância, nada há da evocação melancólica tão peculiar ao gênero: o adulto recusa transmudar as lembranças em id́líio para, numa arte dolorosamente bela, ferir as ilusões e reafirmar o voto negativo ao mundo. Essa aliança difícil de aridez e poesia levou Augusto Meyer a ver no livro uma "beleza intratável”. Ao publicá-lo, em 1945, Graciliano Ramos declarou o seu desígnio circunspecto, contrário portanto à ebriedade sentimental: 
Quer isto dizer que julgue interessante o que narrei? Não, tudo aquilo é chinfrim, mas parece-me referir-se não apenas a um indivíduo, mas às crianças de classe média da minha terra - e, assim, julgo diluir-me no decorrer da narração, confundir-me com outros tipos. Ignoro se consegui essa despersonalização, mas é certo que, se prolongasse as memórias, cairia num egocentrismo besta. E é bom parar naquele primeiro amor absurdo, pouco mais ou menos igual a todos os primeiros amores existentes desde que os homens apareceram. O que farei um dia, se puder... Lá vêm novos planos - e já não estou em idade de traçar planos. A morte anda perto e o diabo leva os planos. O que farei um dia, se puder, é a história de um ano de cadeia, 1936, vivido no pavilhão dos primários, na sala da capela, na colônia correcional de Dois Rios, em outros lugares semelhantes. Os sucessos comuns da minha vida têm pouca importância, mas as criaturas vistas à sombra daquelas paredes hoje me aparecem muito grandes, até os malandros, os vagabundos. Paraíba, um vigarista que me ensinou o pulo-do-gato, Gaúcho, o ladrão que todas as noites me contava em gíria casos do seu ofício. ${ }^{4}$

Na escrita das Memórias do cárcere, Graciliano Ramos gastou, laboriosamente, os seus últimos anos de vida, afinado aliás à disposição que antes calculara: narrar os acontecimentos como quem obscurece a própria presença. Porém, a estratégia humilde não o faz um mero relator; quando se esgueira para a sombra e dali divisa os caracteres, submersos na calamidade, obstina-se no exame das consciências. Sem se instalar no centro dos episódios, o narrador-testemunha estende e impregna o olhar no mesmo golpe, desfiando escrupuloso os véus da exterioridade. Ao fim, as ambiguidades se dobram sobre as certezas íntimas, atordoam o observador que, honesto, se entrega às dúvidas e perquirições. Não faltam, nem mesmo, comentários acerca da ficção, por demais instigantes para o leitor empenhado em analisar a sua obra.

Veja-se esta passagem, exemplar quanto ao trabalho do escritor, cuja poética repassa minúcias e ênfases:

Os jornais tentam comover-nos espichando brigas, e viramos a folha, impassíveis. As facadas e os tiros não nos abalam. Mas o acessório brutal, as formalidades esquisitas, as frases absurdas e insubstituíveis desarrumavam-me conceitos mais ou menos estabelecidos. Isso e a troca infame da pena. Torturavam-me aqueles fatos imprevistos e inverossimeis. Ou não seriam eles que me torturavam: era talvez o reconbecimento da minha insuficiência mental, da incapacidade manifesta de enxergar um pouco além da rotina. Acomodava-me a ambientes novos-e quando neles surgia uma brecha, alarmava-me. Articuladas as peças da narrativa, via-me forçado a achá-la natural. Por que não fizera isso antes, não admitira sem auxílio os casos vergonhosos e medonhos? Evidentemente não podiam ser de outro modo. Afirmava que não podiam ser de outro modo, mas na véspera estivera longe de supor tal coisa. Notava a deficiência e perguntava como diabo me atrevia a fazer obra de ficção. Nada me interessava fora dos acontecimentos observados. Insignificâncias do ramerrão. Umas se reduziam, quase se anulavam, outras avultavam, miudezas ampliadas. Restava saber se era exeqüível uma aparência de realidade isenta da matéria que nos cai debaixo dos sentidos. Essa questão me 
perseguia, muitas vezes me desviava do trabalho maçador, das conversas ociosas na Praça Vermelha. Conseguiria um sujeito livre, em casa, diante de uma folha de papel, adivinhar como nos comportávamos entre aquelas paredes escuras? Tipos iguais a mim seriam incapazes disso. Não se tratava, porém, da minha incapacidade; outros dispensariam exames e sondagens, criariam mentiras de vulto, superiores ao que me caía na pena, mentiras também, povoadas de minúcias rigorosas, exatas. (Ramos, 1954, grifos meus)

Incapaz, a um só tempo, de sumariar os fatos, tracejar-lhes descritivamente os lances gerais, ou de arredá-los em abrupto do campo de visão, o olhar se enviesa, relativiza as versões amplas e as suspeitas particulares. Interroga, sem descanso, as ideias na aparência sólidas, alheias ou próprias, porque em ambas receia a imprecisão. ${ }^{5}$ Decorre daí um inquérito perene, que escava as superfícies e desarmoniza o espírito, sempre vulnerável, aferrando-se às insignificâncias para delas arrancar a semente de sua reflexão. Conforme vemos no trecho digressivo, os fatos atacam muito pouco a sensibilidade do escritor; os pormenores, no entanto, à medida que tocam os avessos e corrigem os contornos, o instigam a observar o evento. Não atina com a grande rede que envolve os ambientes novos, e por isso se exime de apresentar panoramas: as evidências, quer dizer, os signos que saltam aos olhos, só perturbam a razão quando já se esmigalham, se decompõem em ninharias. Esse lastro de resíduos, aparentemente desprezível, constitui os objetos do olhar individual, que sobre eles opera deformações, minguando-os ou alargando-os, a fim de desentranhar os valores ocultos no senso comum. As evidências não se apagam, mas uma vez refletidas nas insignificâncias, se revelam frágeis, dão matéria ao ofício do artista. Num tempo de signos opacos, astuciosamente espalhados como verdades, a pesquisa subjetiva se deve colar aos vestígios insignificantes, e neles colher a sua mentira, isto é, o reverso ideológico.

Nas Memórias do cárcere, pode-se mesmo deparar um primado das insignificâncias, em sua dialética com as evidências, graças à mirada do memorialista em tudo refratário ao discurso em linha reta. Já no capítulo inicial, o procedimento de composição se enuncia nessa ressalva: "Omitirei acontecimentos essenciais ou mencioná-los-ei de relance, como se os enxergasse pelos vidros pequenos de um binóculo; ampliarei insignificâncias, repeti-las-ei até cansar, se isto me parecer conveniente". E dentre as tantas ocorrências do conceito, poeticamente revalorado, destaca-se uma em que o autor se confessa criador minudente e patético: "São as minúcias que me prendem, fixo-me nelas, utilizo insignificâncias na demorada construção das minhas histórias. [...] Comovo-me em excesso, por natureza, e por ofício, acho medonho alguém viver sem paixões". Igual método se nota, simetricamente, no seu tato com a vida social, a qual não espreita sem duvidar das imposturas ordinárias:

sempre me excedera em afirmações categóricas, mais ou menos vãs; achava agora uma base para elas. Evidentemente as pessoas não diferiam por se arrumarem numa ou noutra classe; a posição é que lhes dava aparência de inferioridade 
ou superioridade. Evidentemente. Mas evidentemente por quê? A observação me dizia o contrário. Homem das brenhas, afeito a ver caboclos sujos, famintos, humildes, quase bichos, era arrastado involuntariamente a supor uma diversidade essencial entre eles e os patrões. O fato material se opunha à idéia -e isto me descontentava. Uma exceção rara, aqui, ali, quebrava a monotonia desgraçada: o enxadeiro largava o eito, arranjava empréstimo, economizava indecente, curtia fome, embrenhava-se em furtos legais, chegava a proprietário e adquiria o pensamento e os modos do explorador; a miserável trouxa humana, batida a facão e a vergalho de boi, resistente ao governo, à seca, ao vilipêndio, resolvia tomar vergonha, amarrar a cartucheira à cinta, sair roubando, incendiando, matando como besta-fera. Essas discrepâncias facilmente se diluiam no marasmo: era como se os dois ladrões, o aceito e o réprobo, houvessem trazido ao mundo a condição inelutável: pequenas saliências no povo imóvel, taciturno, resignado. Naquele instante a aspereza do estivador me confirmava o juízo. Lá fora sem dificuldade me reconheceria num degrau acima dele; sentado na cama estreita, rabiscando a lápis um pedaço de papel, cochichando normas, reduziame; despojava-me das vantagens, acidentais e externas. De nada me serviam molambos de conhecimentos apanhados nos livros, talvez até isso me impossibilitasse reparar na coisa próxima, visível e palpável. A voz acre me ofendera os ouvidos, arrancara-me exclamações de espanto, abafadas nas preocupações do Coletivo: ninguém ali estava disposto a lisonjear-me. Aceitei o revés como quem bebe um remédio amargo. Afinal a minha opinião se confirmava. (idibem, grifos meus)

O fragmento desenvolve a reflexão extraída de um incidente entre Graciliano e um estivador irascível. Em reunião do Coletivo, na cadeia, os presos apresentavam suas propostas para organizar-se; diante das ideias de Graciliano, o homem rude usa de desdém e refuta-as. Diluídas, no ambiente carcerário, as diferenças de classe, o trabalhador ainda guarda uma forte reserva a todos os que não se alistam entre os operários, tendo oportunidade então de manifestar o seu rancor: "exibiu sem disfarce ódio seguro aos burgueses, graúdos e miúdos. Todos nós que usávamos gravata, fôssemos embora uns pobres-diabos, éramos para ele inimigos". Graciliano, ofendido, represa em si o impulso de raiva, advindo da surpresa de ver homem tão simplório a insultá-lo, coisa a que não estava habituado fora da prisão: pobre-diabo - isto é, intelectual precariamente remediado -, costumava inspirar respeito aos iletrados, mas ali era alvo de uma ideologia cega. Distinto do estivador condicionado à imediatez dos atos, o narrador suspende a ação em nome da consciência. Também aqui se condensam os dois movimentos: a sua vida interior se ocupa dos aspectos repuxados da realidade em marcha, com as subjetividades nela implicadas, a fim de apreender os estímulos vigentes na estrutura social; enquanto a maioria dos indivíduos se permite arrastar pelas contingências, sem indagar as causas dos seus gestos, o pensamento inquieto se aparta dos eventos para auscultar as razões encobertas na prática coletiva. A suspensão da vida corrente nada tem a ver, nesse caso, com o recolhimento egoísta ante as negaças da existência - é antes o ânimo de vazar as opiniões, rumo à lógica soterrânea. 


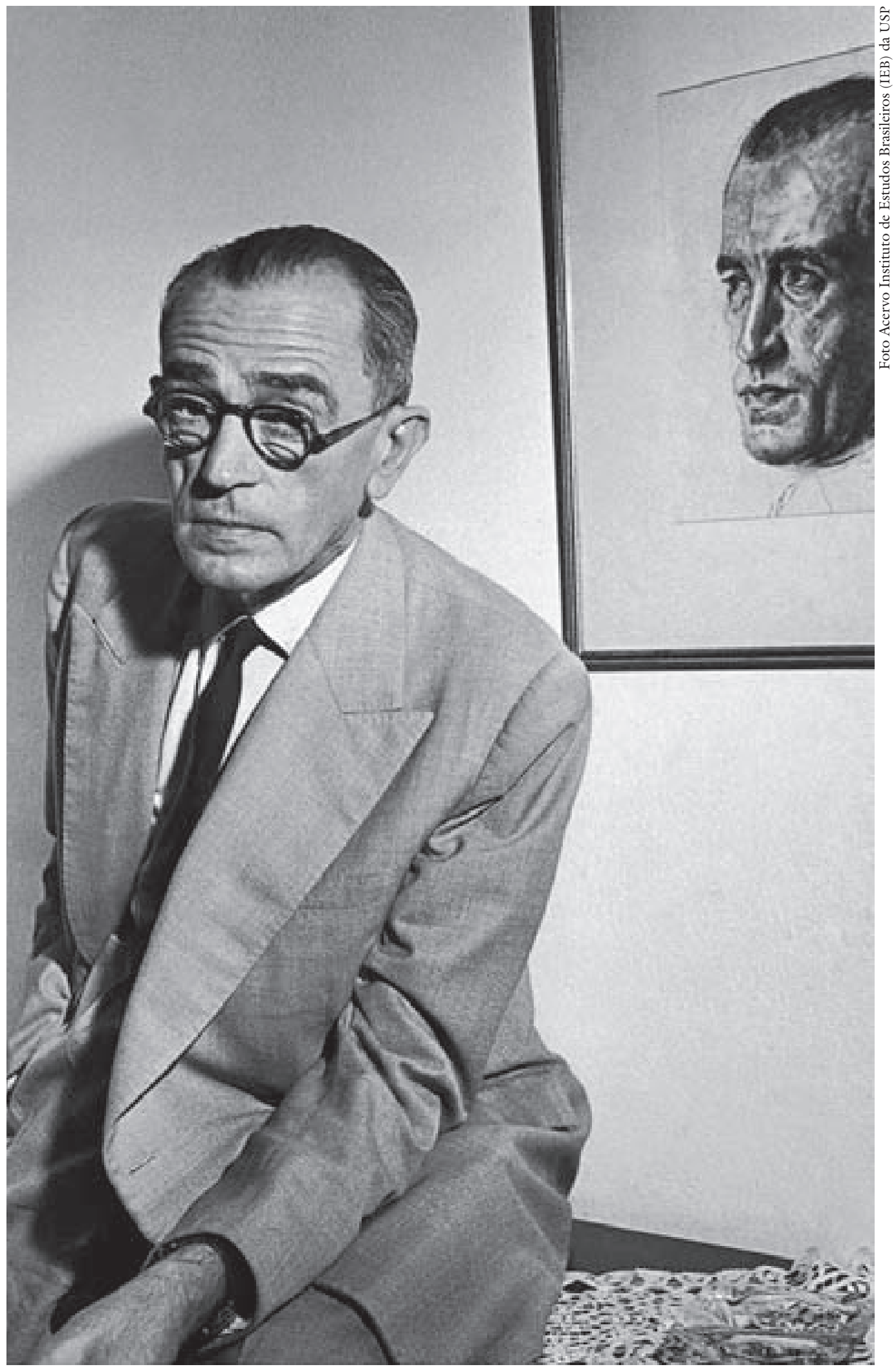

O escritor alagoano Graciliano Ramos (1892-1953). 
$\mathrm{O}$ incidente serve, então, de acicate ao pensamento que se emprega em conhecer o esqueleto da sociedade brasileira, deslizando dos fatalismos: a inesperada brutalidade do operário impele Graciliano a considerar os níveis de relação entre a pessoa moral e a norma. Segundo o trabalhador contraria os modos típicos de sua classe, insurgindo do trato submisso, provoca um susto no escritor; mas logo lhe vem a premissa de que as pessoas carregam tendências semelhantes, sendo estas disciplinadas e exauridas pela ordem. Ideia evidente - porém, a visão da dinâmica social parecia desdizer tal evidência. Num estado de coisas sempre ditado por uma assimetria severa, em que patrões e dependentes trafegavam como imagens tão rigidamente díspares, já se arraigara nas mentes a fatalidade de não supor nenhuma mudança. Raramente, uma figura de exceção derrubava as barreiras e escapava à miséria - o enxadeiro que se fazia proprietário ou o vaqueiro que se rebelava no cangaço. Essas anomalias não chegavam a transtornar as leis comuns, porque contavam com a sua base de violência e subjugação para elevar-se: reproduziam, no fundo, a práxis que até então os vitimara e assim a perpetuavam. De cima e de baixo, todos se obliteram nos condicionamentos de uma atitude reflexa, tragados pela repetência das ações. Quem pode discernir o peso dos reflexos sobre os homens em sociedade é o pobre-diabo, figura instável e fronteiriça, espécie de anfíbio social, que se demite da ação para compreender reflexivamente a máquina ao seu redor. O juízo de Graciliano Ramos se posiciona nesse terceiro ponto, inerte e injuriado, de onde se enxerga o fracasso - o melhor termo para o autor é o de Álvaro Lins: "historiador da angústia". ${ }^{6}$

Não será demasiado averiguar a projeção do raciocínio antes referido nos romances de Graciliano Ramos: os três estratos - o enxadeiro arrivista, o pobrediabo e o vaqueiro humilhado - comparecem em suas obras ficcionais, para demarcar as escalas de nossa sociedade e articular um painel do fracasso. Sem aderir às soluções visionárias, seja a que se exila no passado, seja a que se arremessa ao futuro, Graciliano Ramos se aprofunda em seu lugar de pobre-diabo - cujo observatório se põe na fronteira entre os tempos, sendo um decadente, e entre as classes, não sendo nem possuidor nem despossuído -, e representa o drama de um mundo já falido de nascença, ${ }^{7}$ onde as criaturas expiam uma culpa sem remissão no presente. Parece que os três romances centrais - São Bernardo, Angústia e Vidas secas - se armam com vistas a transfigurar as três esferas da sociedade brasileira (e, no passo seguinte, do capitalismo sem pátria) - o proprietário, o intelectual e o trabalhador -, as quais comungam de igual desventura: o fracasso.

É nesse trabalho de transfiguração literária que se deve perceber o arranjo duplo do escritor: enquanto se dedicava a extrair os critérios específicos da vida social, ao conceber a sua perspectiva, estabilizou uma visão dos fatos e dos indivíduos que a eles se atrelavam; passando, entretanto, ao campo da literatura, cerrou o foco no interior desses indivíduos, vasculhando neles o valor subjetivo que a ordem atrofiara. Ao eleger as figuras tipicas como personagens, e lhes investigar a vida íntima, Graciliano encenou, a um só tempo, o mundo exterior 
que as condicionava e as tensões pessoais que as faziam decair da ação à reflexão - os seus protagonistas trilham o tortuoso caminho que vai do embotamento ao desamparo trazido pelo fracasso, enfim exposto. Trata-se de um espelhamento da busca do escritor sobre o percurso das suas personagens, as quais correm o espaço imprudentes até sentir o espinho da consciência.

De fato, em Caetés, João Valério só ganha importância dramática após vivenciar os reversos dos seus desejos, enfim encurvado sobre os próprios enganos; nos títulos posteriores, em mais aguda tensão, os protagonistas se erigem em entes problemáticos com as vicissitudes e encaram resquícios de pungência. Em São Bernardo, Paulo Honório é o herói do "mundo muito mal arranjado", o coronel bruto que executa os cálculos materiais, mas se desnorteia ao redigir as lembranças ("Talvez deixe de mencionar particularidades úteis, que me pareçam acessórias e dispensáveis. Também pode ser que, habituado a tratar com matutos, não confie suficientemente na compreensão dos leitores e repita passagens insignificantes."), cujo andamento recobra o transtorno amoroso que the exumou a alma eclipsada ("Os fatos mais insignificantes avultaram em demasia"). Angústia precipita o pobre-diabo, que em Caetés se apresenta em germe, numa situação-limite - Luís da Silva encarna o demonismo de um mundo às avessas: arriado da aristocracia até a mendicância, pendura-se no funcionalismo público e rumina a consciência ulcerada de quem sabe deplorar a comédia dos contrários ("um parafuso insignificante na máquina do Estado") - é o dissidente, o anti-herói do mundo envilecido, e excogita em delírio a união com os réprobos ("Milhares de figurinhas insignificantes. Eu era uma figurinha insignificante e mexia-me com cuidado para não molestar as outras"). Vidas secas universaliza o circuito infernizado que antes já asfixiava aquelas almas penadas: os círculos cumprem na justa medida o drama de um mundo sem apelo ao divino, a conversão da epopeia às raias do humano - os sertanejos se espezinham sob a tirania e a ignorância, catando na ilusão um sonho que ainda mais os acorrenta à míngua, malgrado se aninhe no afago solidário ("Que mulher! Assim ele ficaria com a carga aliviada e o pequeno teria um guarda-sol. O peso da cuia era uma insignificância, mas Fabiano achou-se leve, pisou rijo e encaminhou-se ao bebedouro"). Em Infância, o menino infeliz se acabrunha nas asperezas de uma educação agreste, a qual oferece percalços à sua ternura e o martiriza ("E ali permaneci, miúdo, insignificante, tão insignificante e miúdo como as aranhas que trabalhavam na telha negra"); identifica-se apenas ao avô paterno, expulso da lida utilitária e entregue ao artesanato como depois se entragaria o neto à arte da palavra ("Às vezes endireitava o espinhaço, o antigo proprietário ressurgia, mas isto, rabugice da enfermidade, findava logo e o pobre homem resvalava na insignificância e na rede."; "A grandeza e a harmonia singular hoje desdobram a figura gemente e mesquinha, de ordinário ocupada, apesar da moléstia, em fabricar miudezas").

Ocorre que, dentro dos quadros modernos, quando a subjetividade recusa o mundo, parece despropósito representar a sua fusão com o objeto, e a obra 
que assim se compõe, fixando lucidamente o caos, resulta estranha; todavia, o estranhamento, ao fim de contas, é o que sustenta a ironia de estrutura ideada pelo autor. O fator íntimo e o coletivo se casam - um é alimento do outro. Em Graciliano, o melhor termo há de ser testemunho, que é ao mesmo tempo exame crítico e impressão subjetiva de um evento amargado pelo depoente. Os móveis são sociais e a experiência psíquica nunca é compartilhada inteiramente - eis o dilaceramento em que vivem as personagens dos grandes romances modernos, sendo a escrita de confissão uma de suas arremetidas contra o mundo exterior, onde ele se considera um desnaturado.

De toda maneira, se na trajetória da forma romanesca essa encruzilhada perdeu a sua imanência com a iniludível supremacia do objeto sobre o sujeito, tendo de seguir diretrizes novas porque se esfumou o rasgão psicológico, presume-se que aqui os sucessos contraditórios da Revolução de Outubro e a consternação comum alastrada pela Segunda Guerra também retiraram a razão de ser do romance realista. No dizer de Goldmann (1976), "trata-se agora de eliminar dois elementos essenciais do conteúdo específico do romance: a psicologia do herói problemático e a história de sua busca demoníaca"; logo, na literatura europeia tal fenômeno se adensou com o esfarelamento da individualidade, ainda nos princípios do século $\mathrm{XX}$, graças às circunstâncias histórico-econômicas. No caso brasileiro, é de supor, assim, que, se o alcance de autenticidade apenas nos tocou com a narrativa modernista no decênio de 1930, dando vez ao realismo, à proporção que se negavam os seus motivos cessava a pertinência da mesma representação. A década de 1940, com efeito, assinalou a queda de interesse pela realidade brasileira, nos termos propostos até então, e a demanda por formas de mais intensa figuração transcendente, tanto na prosa quanto na poesia, apurada em tonalidades que vão do perplexo ao metafísico. Os circuitos míticos de Clarice Lispector e Guimarães Rosa, por exemplo, recriam as potencialidades da sonda existencial e da épica sertaneja, respectivamente.

Para retomar a hipótese de Carpeaux, a obra de Graciliano Ramos pressente e engendra, em seus traços peculiares, o estilo de mais alta concentração lírica no interregno dos momentos literários. Não será por acaso que o maior nome da chamada Geração de 45 , João Cabral de Melo Neto ${ }^{8}$ enuncia poeticamente a sua afinidade eletiva com o autor de Vidas secas:

Falo somente com o que falo: com as mesmas vinte palavras girando ao redor do sol que as limpa do que não é faca:

de toda uma crosta viscosa, resto de janta abaianada, que fica na lâmina e cega seu gosto de cicatriz clara. 
O poema "Graciliano Ramos" (Serial, 1961) entoa muito além da simples meditação sobre o estilo de um outro admirado: a adjacência do eu-lírico aos ritmos da poética, cuja música áspera jamais se dissipa nas coisas, emaranha as vozes dos dois artesãos. Isso reponta ao leitor de João Cabral, no ouvido de quem ressoam os versos de "A lição de poesia" (O engenheiro, 1945), uma de suas primeiras profissões de fé:

$\mathrm{E}$ as vinte palavras recolhidas

nas águas salgadas do poeta

e de que se servirá o poeta

em sua máquina útil.

Vinte palavras sempre as mesmas

de que conhece o funcionamento,

a evaporação, a densidade

menor que a do ar.

III

Se voltamos ao ano de 1935 - momento em que os rumores de flagelo histórico ganham vulto e atribulam os anseios, em âmbito local e internacional -, apanhamos o romancista em grave descompasso, meio ao vislumbre de suplícios:

Eu sou um literato horrível, e só dou para isso. Tenho procurado outras profissões. Tolice. Creio que meu pai e minha mãe me fizeram lendo o Alencar, que era o que havia no tempo deles. O Estado está pegando fogo, o Brasil se esculhamba, o mundo vai para uma guerra dos mil diabos, muito pior que a de 1914 - e eu só penso nos romances que poderão sair dessa fornalha em que vamos entrar. Em 1914-1918 morreram uns dez ou doze milhões de pessoas. Agora morrerá muito mais gente. Mas pode ser que a mortandade dê assunto para uns dois ou três romances - e tudo estará muito bem. Por aí vê você que eu sou um monstro ou um idiota.

$[\ldots]$

Somos uns animais diferentes dos outros, provavelmente inferiores aos outros, duma sensibilidade excessiva, duma vaidade imensa que nos afasta dos que não são doentes como nós. Mesmo os que são doentes, os degenerados que escrevem conversa fiada, nem sempre nos inspiram simpatia: é necessário que a doença que nos ataca atinja outros com igual intensidade para que vejamos nele um irmão e lhe mostremos as nossas chagas, isto é, os nossos manuscritos, as nossas misérias, que publicamos cauterizadas, alteradas em conformidade com a técnica. (Ramos, 1982) ${ }^{9}$

As inquietações, aqui ditas em escala, perfazem os círculos que, abrindo-se da província ao mundo, reincidem sobre o indivíduo, enforcando-o. Impotente, ao artista da palavra resta a ironia de saber-se fadado ao exercício inútil e, para ele inescapável, de transfundir a experiência histórica em forma literária. Não por acaso, o livro que então arranjava, Angústia, é o emblema dessa agonia, como um prenúncio do desastre já por aterrar os espíritos. Perspectiva trágica 
e sentimento do fracasso: o jogo irônico, capaz de escarnar o cerne falhado do seu tempo, imprime na forma um olhar educado pela desgraça e arredio ao seu império - em momentos de espanto profundo, só um monstro ou um idiota pode romper o silêncio. $\mathrm{O}$ enfermo psíquico, varado de excessos e insignificâncias, tem de abolir-se do mundo e ensimesmar-se, procurar depois na escrita de testemunho, afinada à técnica, o último instrumento com que se fraternizar ao pathos coletivo. A infelicidade que tanto o inferniza, pois está na vida e está nele, deve procurar na linguagem poética uma via de retorno ao público; demuda-se então em arte, mas não dispensa o tom cinzento. $\mathrm{O}$ romance, enquanto mimese crítica da sensibilidade, confere ao escritor um contraveneno para o seu desencanto - embora não o elimine, ao menos o penetra e o comunica. Entretanto, os atentados da história, pisando violentos a realidade, devastaram ainda mais do que o entrevisto e, na trama daquela escala terrível, deitaram um punhado de horror.

O mundo coberto de penas: mover-se no espaço geográfico ou nas camadas sociais não livra ninguém das ruínas. Eis o retrato perverso que se esboça em seus livros. Mas, apesar de tanto se falar do pessimismo de Graciliano Ramos, é preciso conceder que o ódio se revela aqui - nessa luta contra a cegueira - um triunfo: quem recorta no horizonte de seu desconcerto atingir o senso lúcido, se bem mirado o mundo às avessas, não remata a tarefa caso não se inimize com a própria experiência. Trata-se, afinal, de um ódio positivo: salva o sujeito de ser empulhado, torna-se pedra de resistência; e se isso não solve os nós, pois não passa de sentimento do avesso, é ao menos a esperança mínima (diria Drummond) de que a consciência, uma vez semeada, revolucione a ordem das coisas. Contudo, durante os anos de expiação, nada lhe coube a não ser esmiuçar sofrimentos; daí o balanço que faz, depressivo, quando visita o Leste Europeu em franca ressurreição: "Necessário conformar-me: não me havia sido possível trabalhar de maneira diferente: vivendo em sepulturas, ocupara-me em relatar cadáveres" (Ramos, 1970b).

Em verdade, tal estética exprime, na travessia de almas miseráveis, a carga de mágoas e exasperos que se mesclam num processo confuso, revolvem a memória e suprimem o cotidiano - convertem-se, pois, em doença. Ao traduzir as moléstias em técnica literária, o autor arroja as criaturas num mundo nevoento, cujo desequilíbrio rasga uma fresta na consciência: as balizas se apagam e as imagens se refundem magicamente, de modo a iluminar desvãos e remorsos. Para caracterizar esse estado abrasivo, Roger Bastide (2002) lança mão de uma analogia fisiológica: "Como um corpo, pedaço por pedaço, tomba em retalhos sangrentos, assim a vida psíquica - sob a ação de venenos voluntariamente secretos - se destaca em pedaços psíquicos. A composição dos romances de Graciliano Ramos se apresenta assim com toda a sua originalidade: é uma composição por decomposição". ${ }^{10} \mathrm{O}$ narrador opera, assim, autópsias, disseca analiticamente o mundo psíquico tal como se decompõe um organismo doente; explora tumores e febres, órgãos gangrenosos, a partir das células, ou melhor, das partículas in- 
significantes que, embora invisíveis, podem dilacerar. No entanto, a forma não transige com o transe das mazelas, pois a sonda realista se preserva clássica para não se embaraçar nas sinuosidades do desatino. Não há contradição: o equilíbrio de perspectiva se presta ao exame mais justo de um tempo já sem equilíbrio, decide simbolizá-lo para além dos raios evidentes.

Das várias formas literárias que Graciliano tateou (contos, discursos, crônicas, ensaios, quadros regionais, enredos infanto-juvenis, uma breve história da república e até um ato de comédia), à margem da composição de Infância (1938-1945) - índice de sua busca por distintos meios expressivos diante da matéria presente, após a chegada ao Rio, embora a carência financeira também haja influído -, importa ressaltar, nesta discussão, um capítulo de romance feito a dez mãos e, talvez por isso, falhado. ${ }^{11}$ A parte que lhe tocou redigir, "Mário", é a terceira de um conjunto de cinco e firma a vocação dramática do escritor, cuja visada se cerra no empenho aproximativo de um caráter humano; prefere assim deixar de lado o protagonista, um espírito aventureiro, para adentrar a personalidade torturada de Mário, um doente preso à cama e avesso às inconstâncias de Brandão. Todo o relato se fecha na atmosfera nervosa do enfermo, ronda a ambiência de delírio já antes forjada pelo autor; porém agora o olhar narrativo parece cruzar terreno menos espesso, em face do estilhaçamento do sujeito. Ao mesmo tempo que os signos do desajuste íntimo giram na ideia, a falta de vigor problemático faz esvaírem-se as imagens, dispersas sem a costura que alinhava os retalhos da tensão: "Ao cabo de minutos Mário se achava dividido em cem pedaços. E os pedaços cresciam, tornavam-se Mários completos, em pouco tempo havia no quarto uma população de Mários".

O capítulo de abertura apresenta Mário como personagem secundária. Bacharel medíocre, enterrado nas mofinas do casamento e do serviço cacete no escritório do sogro, ele reencontra nas ruas de Salvador o companheiro de juventude Brandão; o amigo, que depois de percorrer o globo em navios se radicou na fazenda do pai com a missão de reerguê-la, lhe capta o abatimento e o carrega em férias para o interior. Lá, a doença o retém hóspede por meses, entocado num quarto. $\mathrm{O}$ texto de Graciliano, sustando o encadeamento de ações, se aperta entre as paredes do aposento e se infiltra na dispersão crispada da personagem: os volteios do desejo the cindem continuamente o ânimo, sempre febril, a ponto de nunca remendar as porções do tumulto e dissipar a neblina. $\mathrm{O}$ andamento enrodilhado, entretanto, apesar de pendular entre os extremos - a rotina e a quimera, a esposa azucrinante e a mulher misteriosa, o cotidiano e as viagens -, beirando a rarefação, não infringe por completo o estatuto realista do narrador, que com isso experiencia o discurso evanescente apenas até o limite do indivíduo:

Concentrou-se, reuniu os cacos da sua pessoa atropelada, sacudida, rebentada e incompleta, composição absurda. Por que não procede como o médico de Alagoinha? O médico de Alagoinha não vê no doente um indivíduo: vê uma coleção de órgãos avariados. Ocupa-se ora de um, ora de outro, sem atentar no 
conjunto. Mário tenta adotar o processo do homem, esforça-se por isolar um sentimento, arranjar-lhe uma designação, decompô-lo, rotular as partes obtidas. Terá enfim uma grande quantidade de pequenos desgostos inofensivos. Trabalho inútil. A coisa dolorosa é indivisível. A combinação de peças incongruentes está contaminada. De fato não há peças. Parece que Mário se derreteu num calor de fornalha, solidificou-se pouco a pouco. E o desejo, imenso, está em todo o corpo. (Amado, 1973)

Note-se que o procedimento objetivo do médico, espécie de autópsia de corpo vivo, nenhum alcance tem sobre o todo difuso da subjetividade. Ambos, narrador e personagem, o rejeitam por inócuo, mas em níveis de apreensão diferentes: este não cede à dispersão plena do seu drama, embora tampouco consiga ordená-lo e logo sucumbe; aquele surpreende as nervuras de uma alma espedaçada e, evitando tropeçar no foco múltiplo, conserva-se no posto de observador. Como se vê, é ímpar o ângulo que o romancista testou para abordar o problema, sem propriamente solucionar o impasse. $\mathrm{O}$ mais curioso é que, numa narração breve de vinte páginas, ele tenteia os dois pontos de vista, dando prova de desaprumo no tratamento - o último trecho, uns poucos recortes do caderno de Mário, assume a primeira pessoa. E aí sobe ao plano central a errância do sujeito perante o seu trançado afetivo: quando retrata os seres em derredor, é capaz de enunciar apreciações que o isolam do convívio, mas escorregando nas reminiscências, tudo se evapora nos refluxos da infância:

Preciso aliviar-me, converter-me em criança, pular na areia de pés descalços, ver os balões coloridos voarem no céu em noites de São João. Aquecer-me a fogueiras humildes em noites de São João, esquentar estas mãos trêmulas e molhadas. Depois, depois... Voarei como um balão. Quando retirarem desta imundície todo o sangue ruim. Trinta e sete e meio, trinta e oito, trinta e sete e meio. Meu Deus, como é doloroso! Ficarei leve e subirei, balão colorido em noite de São João. Irei cair longe, muito longe, e não me lembrarei disto. Serei outra coisa, outras coisas, livres disto. (ibidem)

Com efeito, essa tentativa de volta ao romance no decênio de 1940, em certa medida malfadada, assinala, justamente com o desacerto, a intuição do escritor quanto à necessidade de reformar a perspectiva e, também, o seu afinco ao estilo crítico. Se, de um lado, se abalança a esquadrinhar a disposição flutuante do indivíduo, mergulhado numa época de embates e névoas, de outro, guarda ainda alguma distância que não lhe consente turvar a ironia. ${ }^{12}$ Sendo parcela de romance coletivo, não organiza a síntese do conto nem se integra nos planos de trama analítica. Em sua ficção de 1930, Graciliano operava com o delírio hiatos no enredo, instantes de raro amálgama nos quais alheamento e retentiva se fundiam para alumiar o núcleo dramático (o capítulo 19 de São Bernardo, o trecho final de Angústia, a agonia de Baleia, a febre de Alexandre); ora o recurso vira fumaça, não atinge o vértice do conflito e se espalha sem atravessar a realidade. ${ }^{13}$ O resultado é emprestar voz à personagem, cuja excitação não vence a melancolia, e assim senti-la escorrer inteira no inefável. 


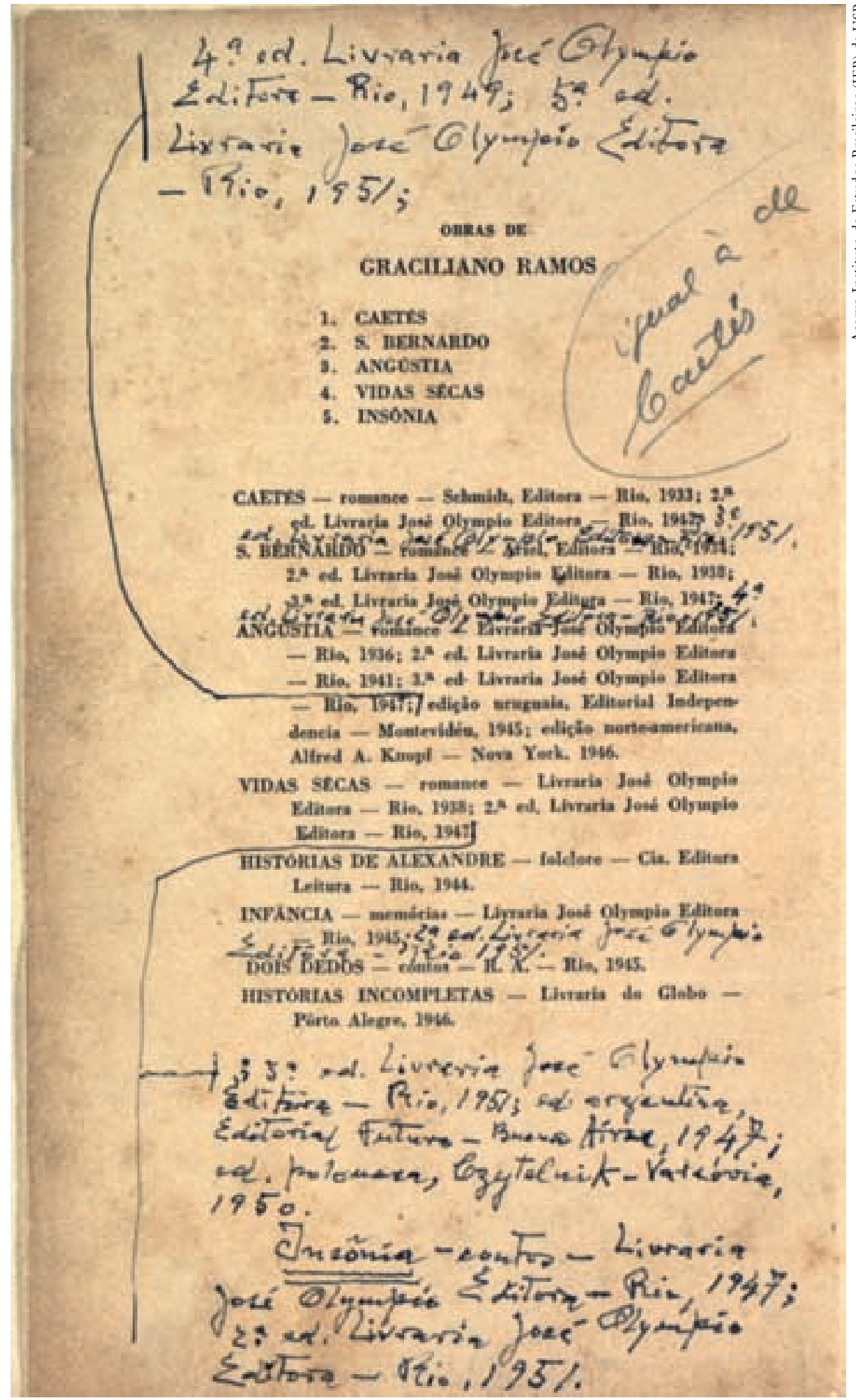

Emendas manuscritas solicitadas por Graciliano Ramos à Editora José Olympio. 
Muito diverso se mostra, como ficou dito antes, o arranjo evocativo do autor: em vez de refúgio dos tempos duros, a memória crava na infância os germes de solidão e castigo. O pretérito reconcentra, em escritos curtos, os sinais da aprendizagem ríspida e do olhar que se enviesa meio aos objetos nublosos - desponta, em diacronia, o crepúsculo de pesares. Em "Cegueira”, por exemplo, a doença de olhos prostra o menino sob a dor física e moral, baralha a visão e rende insultos. O mundo lhe sobrevém distorcido ("Os objetos surgiam empastados e brumosos"), arredando-o ainda mais dos usos comuns, mas também se dilata em frações insuspeitas, pontos de fuga que revelam obliquidades ("Na escuridão percebi o valor enorme das palavras"). Há nesse claro-escuro, cambiante, a instabilidade anímica que tanto o molestou na infância; há, por outro lado, o rastro biográfico de sua poética, fincada no olhar ambíguo que se arrevesa, instável, para descobrir o pulso da realidade. A visão oblíqua, à medida que embaça a esfera concreta, recata-a nas bagatelas: "E meses depois, nova pausa, novo mergulho na sombra. Movia-me penosamente pelos cantos, infeliz e cabra-cega, contentando-me com migalhas de sons, farrapos de imagens, dolorosas" (Ramos, 1953).

A célebre passagem de "Manhã", na qual Graciliano Ramos pesquisa o próprio estilo por analogia implícita com a arte do avô, ancora na rispidez tanto a matéria danosa quanto a expressão. Testemunhar um estado de coisas severo exige do artesão reproduzir a severidade e, dialeticamente, engastar nela as digitais. A tenacidade do antepassado, absorto no amanho de inutilidades precisas, comunica ao escritor o rigorismo e o calco singular: as urupemas que o velho urdia, peneiras rústicas, são a metáfora do lírico estranho, capaz de coar os grãos e as insignificâncias:

Suou na composição das urupemas. Se resolvesse desmanchar uma, estudaria facilmente a fibra, o aro, o tecido. Julgava isto um plágio. Trabalhador caprichoso e honesto, procurou os seus caminhos e executou urupemas fortes, seguras. Provavelmente não gostavam delas: prefeririam vê-las tradicionais e corriqueiras, enfeitadas e frágeis. $\mathrm{O}$ autor, insensível à crítica, perseverou nas urupemas rijas e sóbrias, não porque as estimasse, mas porque eram o meio de expressão que lhe parecia mais razoável. (ibidem)

Notas

1 Em seu ensaio "O fator econômico no romance brasileiro", após reclamar a fusão dos elementos objetivo e subjetivo como fundamento da estrutura narrativa, Graciliano (1970a) assim estabelece a posição do escritor em face da sua matéria: "Estamos diante de um fato. Vamos estudá-lo friamente./ Parece que este advérbio não será bem recebido. A frieza convém aos homens de ciência. $\mathrm{O}$ artista deve ser quente, exaltado. $\mathrm{E}$ mentiroso./ Não sei por quê. Acho que o artista deve procurar dizer a verdade. Não a grande verdade, naturalmente. Pequenas verdades, essas que são nossas conhecidas”.

2 Penso na categoria tal como a formulou Lukács (2000): “A composição do romance é uma fusão paradoxal de componentes heterogêneos e descontínuos numa organici- 
dade constantemente revogada. As relações que mantêm a coesão dos componentes abstratos são, em pureza abstrata, formais: eis por que o princípio unificador último tem de ser a ética da subjetividade criadora que se torna nítida no conteúdo. Mas como esta tem de superar-se a si própria, a fim de que se realize a objetividade normativa do criador épico, e como nunca ela é capaz de penetrar inteiramente os objetos de sua configuração, nem portanto de despojar-se completamente de sua subjetividade e aparecer como o sentido imanente do mundo objetivo, ela própria necessita de uma nova autocorreção ética, mais uma vez determinada pelo conteúdo, a fim de alcançar o tato criador de equilíbrio. Essa interação entre dois complexos éticos, a sua dualidade no formar e a sua unidade na figuração, é o conteúdo da ironia, a intenção normativa do romance, condenada, pela estrutura de seus dados, a uma extrema complexidade".

3 Tome-se o agudo apontamento de Antonio Candido (1999) sobre a originalidade do problema: "Graciliano Ramos usou um discurso especial, que não é monólogo interior e não é também intromissão narrativa por meio de um discurso indireto simples. Ele trabalhou como uma espécie de procurador do personagem, que está legalmente presente, mas ao mesmo tempo ausente. O narrador não quer identificar-se ao personagem, e por isso há na sua voz uma certa objetividade de relator. Mas quer fazer as vezes do personagem, de modo que, sem perder a própria identidade, sugere a dele. Resulta uma realidade honesta, sem subterfúgios nem ilusionismo, mas que funciona como realidade possível".

4 Arquivo Graciliano Ramos - IEB/ USP; Série: Manuscritos; Pasta: Discursos.

5 Estudando o livro, Alfredo Bosi (1995) depreende o modo de o autor cercar os sentidos subjacentes aos contextos: "A força da palavra de Graciliano nestas memórias vem da sua coragem de relativizar tanto as versões alheias quanto as próprias. É um exercício de dúvida que não chega a paralisar a enunciação, mas a torna modesta. A pergunta é freqüentemente o seu bordão metódico"; e no fecho do ensaio: "Memórias do Cárcere: nesta obra realista e clássica a modernidade se afirma pelo reconhecimento da força e dos limites do sujeito".

6 O crítico assim define a visada de Graciliano Ramos: "Observa-se, por isso, que a veridicidade do romance do Sr. Graciliano Ramos é uma realidade estática, não dinâmica. [...] Por isso é que do seu romance se depreende mais a 'história' de uma angústia do que a 'angústia' em si mesma. Uma angústia racionalizada e histórica, não uma angústia natural e presente. O estado de delírio, de exaltação, de demonismo, o estado dionisíaco capaz de exprimir a angústia - este não será nunca o do Sr. Graciliano Ramos. O seu estado pode-se definir como o do historiador da angústia” (Lins, 1943).

7 Essa questão, fundante para a realidade brasileira, ainda persiste hoje, embora se aponte um lento processo de mudanças, como centro mesmo de nosso naufrágio histórico; por isso, na última década, Darcy Ribeiro (2002) reforça a presença do problema a conformar, desde sempre, o atraso nacional: “o malogro dos nossos esforços de nos estruturarmos solidariamente, no plano socioeconômico, como um povo que exista para si mesmo. Na raiz desse fracasso das maiorias está o êxito das minorias, que ainda estão aí, mandantes. Em seus desígnios de resguardar velhos privilégios por meio da perpetuação do monopólio da terra, do primado do lucro sobre as necessidades e da imposição de formas arcaicas e renovadas de contingenciamento da população ao papel de força de trabalho superexplorada".

8 Avaliando o fim do prestígio da objetividade na literatura nacional e a preponderância 
poética da nova fase, inclusive entre sobreviventes daquele período, João Cabral de Melo Neto (1990) afirma: “certos valores foram substituídos, muitos deles pelos valores opostos aos que prevaleceram a partir de 1930. Outros dos valores introduzidos vão de encontro ao movimento de apreensão da vida brasileira pregado pelos modernistas de 1922. E outros, enfim, vão contra a própria tradição da Literatura Brasileira e contra o que parece lícito esperar-se da literatura de um país em construção. / O que parece existir por debaixo nos novos valores introduzidos poderia ser resumido dizendo-se que são portas para fugir da realidade que se reclama dos escritores de hoje. Para isso, substituiu-se o objetivo pelo subjetivo; o real pelo sobre-real; deixou-se de exigir de uma obra comunicação para exigir-se expressão; passou-se a renunciar ao que na literatura pode ser instrumento de influência coletiva em nome do que, nela, pode satisfazer a certas necessidades interiores, egoístas por sua exclusividade. Em resumo: passou-se a desprezar o que um livro vai ser capaz de realizar, uma vez publicado, e a valorizar-se o que um livro foi capaz de realizar, ao ser escrito".

9 A carta data de 3 de abril de 1935.

10 O texto de Bastide foi originalmente publicado em O Estado de S. Paulo, São Paulo, 30.3.1947.

11 Trata-se de Brandão entre o Mar e o Amor. Publicado capítulo a capítulo pela revista Diretrizes, em 1941, e em feitio de livro pela Editora Martins, em 1942, o romance reuniu, além de Graciliano Ramos, Jorge Amado, José Lins do Rêgo, Aníbal Machado e Rachel de Queiroz, ficando cada qual responsável por uma parte. Os estilos tão díspares e a ausência de unidade no entrecho impediram a coesão da fatura. Poucos anos depois, num discurso proferido no Partido Comunista, acerca de questões em torno da perspectiva literária e política do escritor engajado, Graciliano chega a dizer: "De que modo se realiza a produção? Evidentemente é razoável que os eruditos se associem: não conceberíamos a Enciclopédia Britânica redigida por uma pessoa. A criação, porém, é rigorosamente individual: absurdo imaginarmos quadros e poemas compostos por diversas criaturas; tentativas malograram-se; aqui há tempo alguns literatos fabricaram, com infelicidade notável, uma espécie de romance - um desastre" (Arquivo Graciliano Ramos-IEB/ USP; Série: Manuscritos; Pasta: Discursos).

12 Em termos genéticos, é revelador o contraste das duas versões que o autor escreveu. $\mathrm{Na}$ primeira, ensaia maior empatia com a personagem, quase rente à sua dicção, conforme se lê no início: "Bonito! Alguns dias de férias, quase um passeio, para afastar as chateações de cada dia, tinham dado naquilo. Acanhava-se, via perfeitamente que estava ali aperreando, incomodando". Já a segunda, que efetivamente se publicou, torce a tonalidade em sentido oposto, frisando o distanciamento de miradas e adensando o travo sombrio: "Desastre. Umas férias curtas para afastar os desgostos ordinários tinham dado naquilo. Envergonhava-se, reconhecia-se inútil e incômodo" (Arquivo Graciliano Ramos - IEB / USP; Série: Manuscritos; Pasta: Brandão entre o Mar e o Amor).

13 Ao estudar o impressionismo dissolvente que moveu a crise do romance psicológico, abolindo da narrativa as instâncias temporais, Anatol Rosenfeld (1996) aponta a relativa adesão de Graciliano, cujos romances assimilam, em seus círculos dramáticos, apenas em certo grau a dissolvência: "Mesmo num romance como Angústia, de Graciliano Ramos, que não adota processos muito radicais, se nota intensamente essa preocupação: o passado e o futuro se inserem - através da repetição incessante que dá ao romance um movimento giratório - no monólogo interior da personagem que se debate na sua desesperada angústia, vivendo o tempo do pesadelo". 
Referências bibliográficas

AMADO, J. et al. Brandão entre o Mar e o Amor. São Paulo: Martins, 1973.

BASTIDE, R. O mundo trágico de Graciliano Ramos. Teresa - Revista de Literatura Brasileira, São Paulo, n.2, 2002.

BOSI, A. A escrita de testemunho em Memórias do cárcere. Estudos Avançados, v.9, n.23, 1995. Republicado em Literatura e Resistência, S. Paulo, Cia. das Letras, 2002.

CANDIDO, A. 50 anos de Vidas secas. In: . Ficção e confissão. São Paulo: Editora 34, 1999.

CARPEAUX, O. M. Visão de Graciliano Ramos (Prefácio). In: RAMOS, G. Angústia. Rio de Janeiro, Record, 1986.

Tendências do moderno romance brasileiro. In: Ensaios reunidos (19461971). Rio de Janeiro: Topbooks, 2005.

GOLDMANN, L. Introdução aos problemas de uma sociologia do romance. In: A sociologia do romance. Rio de Janeiro: Paz e Terra, 1976.

LINS, A. Jornal de crítica. Rio de Janeiro: José Olympio, 1943.

LUKÁCS, G. A teoria da romance. São Paulo: Editora 34, 2000.

MELO NETO, J. C. de. Esboço de panorama. In: Obra completa. Rio de Janeiro: Nova Aguilar, 1990.

RAMOS, G. Infância. Rio de Janeiro: José Olympio, 1953.

- Memórias do cárcere. Rio de Janeiro: José Olympio, 1954.

. O fator econômico no romance brasileiro. In: . Linhas tortas. São Paulo, Martins, 1970a.

. Viagem. São Paulo: Martins, 1970 b.

. Cartas. Rio de Janeiro: Record, 1982.

RIBEIRO, D. O povo brasileiro. São Paulo: Cia. das Letras, 2002.

ROSENFELD, A. Reflexões sobre o romance moderno. In: Texto/contexto. São Paulo: Perspectiva, 1996.

RESUMO - Atido ao problema do estilo literário, o ensaio procura investigar a disposição dramática que, na obra de Graciliano Ramos, enforma os romances e se adensa nas memórias. Após haver forjado a sua técnica pessoal nas narrativas de 30, superando as vertentes opostas do período (materialista e espiritualista) num realismo dialético, o escritor derivou para a autobiografia a fim de não dissipar o jogo das tensões. A leitura percorre, logo, os caminhos de tal arranjo estilístico, com vistas a pesquisar a unidade do olhar ambíguo na variação de formas, seguindo a hipótese de que se a perspectiva dramática do autor já não cabia, por força das pressões históricas, no romance dos anos 40 , reconcentrou-se nas memórias.

PALAVRAS-CHAVE: Graciliano Ramos, Romance, Memória, Estilo dramático 
ABSTRACT - Focused on the problem of literary style, the essay investigates the dramatic disposition, that, in Graciliano Ramos' work, forms the novels and deepens in the memories. After having created his personal technique in the narratives of the 30's, surpassing the opposite tendencies of the period (materialistic and spiritualistic) in a dialectical realism, the writer derived to the autobiography, in order to not dissipate the set of tensions. Therefore, the reading courses the paths of this style, in order to find the unity of the ambiguous view in varying ways, following the hypothesis that, if the author's dramatic perspective was not suitable in the novel of the 40's, because of the historical pressures, he concentrated on the memories.

KEYWORDS: Graciliano Ramos, Novel, Memory, Dramatic style.

Erwin Torralbo Gimenez é professor de Literatura Brasileira na Universidade de São Paulo (USP). @-torralbo@usp.br

Texto recebido em 20.9.2009 e aceito em 30.9.2009. 